ANNALS, $A A P S S$, 473, May 1984

\title{
The Changing of the Guard: The New American Labor Leader
}

\author{
By ARTHUR R. SCHWARTZ and MICHELE M. HOYMAN
}

\begin{abstract}
This article analyzes recent changes in the leadership of international unions. There has been a trend toward leaders who are lifetime bureaucrats rather than rank-and-file members with charisma. This change toward more technocratic leadership is due to the different environment and new challenges that labor currently faces. The United Mine Workers is a good example of a union that has had many changes in the type of person who has become president, from the labor giant John L. Lewis to the 33-year-old lawyer Richard Trumka. The United Auto Workers is an example of a union whose leadership has been consistently drawn from the union hierarchy. The AFL-CIO has made a change in leadership from George Meany to the labor bureaucrat Lane Kirkland. There will probably be an increase in the number of women and minorities in top leadership positions in unions, but this will be a gradual increase.
\end{abstract}

Arthur R. Schwartz is an assistant research scientist at the Institute of Labor and Industrial Relations, University of Michigan. His research interests include the economic impact and changing nature of collective bargaining. He received his Ph.D. in economics from the University of Michigan.

Michele M. Hoyman is an assistant professor at the University of Missouri-St. Louis. Her research interests include the impact of government regulation on unions as well as women's participation in unions. She received her Ph.D. in political science from the University of Michigan. 
$\mathrm{I}^{\mathrm{N}}$ $\mathrm{N}$ any organization the leader has a great impact on overall direction and policy. This is especially true of labor unions. Many labor leaders have put their stamp on a union that lasts beyond their lifetime. For example, the adherence of the AFL-CIO to the political philosophy of Samuel Gompers is one reason there never has been a successful labor party in the United States.'

In this article we attempt to look at the new breed of labor leader. In doing so, we examine the old labor leader and the changing role of unions in society. The emphasis is on international union presidents, although there is also some discussion of lower-level officers and union staff. We examine briefly the job of a union president and union election procedures. We then present case studies of presidential succession in three unions, followed by a look at the inroads that women and minorities have made into union leadership positions. Finally, we conclude with some thoughts about the labor leader of the 1990s. Although our comments apply generally to the entire labor movement, they are most applicable to the large industrial unions, and we thus focus most of our attention on those unions.

\section{LABOR LEADERS YESTERDAY AND TODAY}

The great leaders have either died or retired, and a new generation of labor leader has come to power. The presentday union leader is likely to carry a briefcase, look like a business executive,

1. See for example, Michael J. Piore, "Can the American Labor Movement Survive Re-Gomperization?" in Proceedings of the Thirty-fifth Annual Meeting of the Industrial Relations Research Association (Madison, WI: IRRA, 1983), vol. 30 . and sport an undergraduate or professional degree. In other words, the modern labor leader may look less like their rank-and-file members than like their counterparts on the management side of the table. The labor leaders of the past had less education. They started out working on the shop floor of the plant or the mill and had a strong ideological commitment. The new breed of union leader has more formal education and fewer direct roots in the working class. The new labor leader may be less pugilistic, less rough and ready, and more sophisticated and accommodating.

One of the major changes in the union presidency is the road to the top. Historically there was only one road, and that was up from the rank and file. Today there are three primary paths: the traditional rank-and-file road, the rise from within the union bureaucracy, and the route of the outside professional who moves directly into union leadership. Most of the old leaders provide examples of the first way. Lane Kirkland is one leader who used the second route, since his power came from "his mastery of the skills needed to run a large organization and from his absorption in the details of labor relations and social policy." 2 Richard Trumka, the newly elected president of the United Mine Workers (UMW) represents the third route: the professional-here, a lawyer - who moves to the presidency on the basis of expertise, not all of which is gained directly from the labor movement.

One essential difference between the new and old guard in the labor movement is the position of organized labor

2. Joel Denker, Unions and Universities (Montclair, NJ: Allanheld, Osmun, 1981), p. 105. 
in society. Many of the earlier leaders were in power during the formative years of the labor movement in the United States. Harry Bridges began his term in 1937 and John L. Lewis in 1919; Walter Reuther was active in the United Auto Workers in the 1930s. These were years in which labor was fighting for simple recognition.

In the 1980s the threats to labor come from different directions, since unions are now a fact of life in the United States, protected by law. The modern day threats come from firms that peddle union-free environments; from the changing demographic characteristics of the work force, which pose challenges to unions' organizing efforts; and from the changing industrial structure in the United States. Leading a union in a period when overall union growth has slowed and many traditional, smokestack industries are facing a long-run decline in employment requires a different type of labor leader, one that is skilled in the technical aspects of unions as well as the details of organizing.

\section{JOB OF THE \\ UNION LEADER}

International unions vary greatly in their structure, their history, and their size, so it is difficult to make a single and universally applicable statement about the job of a union president. The modern labor leader, as its top elected official, must still represent the membership of the union. However, there are multiple constituencies for the contemporary labor leader, making a substantial amount of role conflict inherent in the office. These constituencies include the members of the union; other international union leaders, such as the AFLCIO Executive Board; the staff members of their union, and the other members of a national political elite.

Today's union leader must also be a technocrat-with responsibilities for compliance with federal and state law on union elections, pensions, equal employment, and occupational safety and health as well as to the numerous labor laws that have historically regulated the organizing and collective bargaining activities of unions. The contemporary labor leader is also a manager, since union bureaucracies have grown very large in the last 30 years. The union leader manages a large permanent staff and must solve all the internal problems that arise in supervising that staff, including, in recent years, even bargaining with staff unions that have been formed.

There are other aspects of a union president's job. The modern labor leader is an important actor on the national political scene. In addition, the union president still serves for the most part as the chief bargainer for the union. In short, the many demands on a contemporary union leader may resemble those experienced by local union leaders that Sayles and Strauss described nearly two decades ago. ${ }^{3}$

\section{CHOOSING A LEADER}

Theoretically, union leaders are selected democratically. The procedures for selecting union leaders are regulated by the government in the United States through the Landrum-Griffin or Labor-

3. Leonard Sayles and George Strauss, The Local Union, Its Place in the Industrial Plant (New York: Harper, 1953); and Martin Estey, The Unions: Structure, Development and Management (New York: Harcourt Brace Jovanovich, 198I). 
Management Reporting and Disclosure Act of 1959.4

The methods that individual unions use to elect their presidents vary. A few unions, such as the United Mine Workers and the United Steelworkers, have direct election of their presidents by the membership. One union, the International Typographical Union, actually has a two-party system. ${ }^{5}$ The most common method of choosing a president is by convention. In most cases there is only one slate of candidates that is endorsed by the executive board. That slate is almost always elected, although incumbents have been defeated on occasion. ${ }^{6}$

Turnover among union leaders tends to be rather low. Between 1948 and 1967 , the average turnover rate for union presidents was approximately 20 percent per year. Most of the turnover was due to retirement or failure to run for reelection. ${ }^{7}$ Turnover from 1971 to 1979

4. For two excellent studies of the impact of Landrum-Griffin, see Doris McLaughlin and Anita L. Schoomaker, The Landrum-Griffin Act and Union Democracy (Ann Arbor: University of Michigan Press, 1979), and Janice Bellace and Alan Berkowitz, The Landrum-Griffin Act: 20 Years of Federal Protection of Union Members Rights (Philadelphia: University of Pennsylvania, 1978).

5. Derek C. Bok and John T. Dunlop, Labor and the American Community (New York: Simon and Schuster, 1970), p. 494.

6. For example, Albert Shanker defeated David Seldon for the presidency of the American Federation of Teachers in 1974, and Walter Reuther wrested the presidency of the UAW at the 1946 convention. For a description of the 1946 UAW convention, see Victor G. Reuther, The Brothers Reuther (Boston: Houghton Mifflin, 1979), p. 258.

7. Marvin Snowbarger, "Reply to Professor Koziara" (comment on "Landrum-Griffin and Union President Turnover"), Industrial Relations, 11(1): 120 (Feb. 1972). was somewhat higher, at approximately 25 percent. ${ }^{8}$

One implication of the relatively small turnover of union presidents is that the tenure in office tends to be quite long. For example, Harry Bridges was president of the Longshoremen from 1937 to 1977; John L. Lewis headed the UMW for 41 years; and the AFL has had only four presidents from 1886 to 1983.9

\section{PATHS TO THE PRESIDENCY}

What follow are three case studies that illustrate various routes taken to union leadership.

\section{The United Mine Workers}

The UMW is a good example of the trend of leadership change that has developed in the labor movement. For over 40 years the union was headed by John L. Lewis, who turned the UMW into a labor autocracy. ${ }^{10}$ Lewis did not really face an electoral challenge of any substance after 1927. He ran the UMW with an iron hand until his retirement at age eighty in 1960.

Following the brief presidency of Tom Kennedy from 1960 to 1963, W. A. ("Tony") Boyle became president. He

8. Of the 175 changes in union presidents over the period $1971-79,52$ (30 percent) were due to retirement, 62 (35 percent) due to resignation or failure to seek a new term, and 18 ( 10 percent $)$ due to death. Only 22 , or 12.5 percent, were due to election defeat. This information was gathered from U.S., Bureau of Labor Statistics, Directory of National Unions and Employee Associations (Washington, DC: Department of Labor, 1973, 1975, 1977, 1979).

9. For the AFL this does not count the presidency of John McBride of the UMW, 1894-95.

10. Paul F. Clark, The Miners' Fight for Democracy (Ithaca, NY: Cornell University, 1981), p. 5. 
had been a vice-president of the union and prior to that had been assistant to the president for 12 years. He came through the union hierarchy, having also been at one time the president of the Montana coal miners." The administration of Tony Boyle has been well documented for its corruption, culminating in the brutal murder of rival union candidate Jock Yablonski, his wife, and daughter in $1969 .{ }^{12}$ This caused the formation of Miners for Democracy and the challenge of Arnold Miller, who defeated Boyle in the election of 1972.

Miller was a rank-and-file reformer with little experience in union administration. Ill health forced his resignation in 1979 amidst general disenchantment of the union staff over his efforts. ${ }^{13}$ Miller was succeeded by Sam Church. Church had been a local president, a field representative, an international representative, and finally UMW vicepresident in $1977.14 \mathrm{He}$ was in many ways an example of the union bureaucrat coming to the top, although he certainly did have rank-and-file credentials.

In 1982 he was challenged by Richard Trumka, a 33-year-old lawyer and former member of the UMW legal staff who was at the time a member of the International Executive Board from UMW District Four, which is western Pennsylvania. ${ }^{15}$ Church had become unpopular during the strike of 1981, and there was the general feeling that the UMW was in decline. By a two-to-one margin, Trumka was elected as the new UMW president. He had campaigned vigorously on the theme of increasing

11. Ibid., p. 19.

12. Ibid., p. 26.

13. Ibid., pp. $27,136$.

14. Ibid., p. 137.

15. "A Militant Miner Worries Industry," Business Week, 13 Sept. 1982. membership and halting the decline in the union's membership and power. ${ }^{16}$

The UMW provides an interesting case study of the different paths to leadership. In the 23 years from 1960 to 1983 , they have moved from the giant Lewis through the corrupt Boyle, the rank-and-file reformer Miller, the union bureaucrat Church, and the young, urbane lawyer Trumka. Part of the recent trend could be due to the decline in membership from 450,000 in 1962 to 245,000 in $1980 . .^{17}$ It appears that in order to reestablish the UMW as a major union in the face of a growing nonunion sector, a slumping economy, and increased mechanization, the union turned to a professional who could speak for the union from a position of expertise-someone who could deal with government and management on their level. Whether this trend continues will of course depend on the success of the presidency of Richard Trumka.

\section{The United Auto Workers}

The change in the type of leadership of the UMW can be contrasted with the stability in the United Auto Workers (UAW). From 1946 to 1983, the UAW has had four presidents. All of them reflect the same path: from the rank and file, to the union bureaucracy, to the presidency. Walter Reuther is considered, like Lewis, a giant of the labor movement. He came from a workingclass background, attended some college, and had a social reformer's political program. ${ }^{18} \mathrm{He}$ rose from the position

16. Geroge Ruben, "Collective Bargaining in 1982: Results Dictated by Economy," Monthly Labor Review, 106(1):36 (Jan. 1983).

17. Courtney D. Gifford, ed., Directory of U.S. Labor Organizations, 1982-83 (Washington, DC: Bureau of National Affairs, 1982), p. 70.

18. Reuther, The Brothers Reuther, pp. 44-70. 
of vice-president in charge of the General Motors department to become president of the union in 1946. Reuther was a very charismatic leader who, through sheer force of personality, often was able to carry the entire union with him.

After the death of Reuther in 1970 , Leonard Woodcock became president and served until 1977. Woodcock rose to his position from the vice-presidency in charge of the General Motors department, the same springboard used by Reuther. Woodcock had attended college, and he too was active in the formative years of the UAW. He spent a long time in the UAW bureaucracy and is an example of a union bureaucrat making it to the top. ${ }^{19}$

When Woodcock had to retire upon reaching the mandatory retirement age of 65 , he was succeeded by Douglas Fraser, who at the time headed the General Motors department of the UAW. He had been in the union bureaucracy since shortly after World War II. He narrowly lost the presidency in 1970 and was the unanimous choice in 1977. He was a charismatic leader more in the Reuther mold than in the Woodcock mold. Even though the union was losing members and he had to preside over a series of concession agreements, Fraser kept his personal popularity. He was acclaimed by leaders of labor and business alike as a statesman. ${ }^{20}$

The retirement of Fraser upon reaching age 65 makes the break with the Reuther generation of leadership. However, the new president, Owen Bieber, followed the same path to leadership as

19. Doris McLaughlin, "A Conversation with Leonard Woodcock," Michigan Quarterly Review, 21(4):531 (Fall 1982).

20. Ralph Orr and Billy Bowles, "The Making of Doug Fraser," Detroit Free Press, Detroit Magazine, 3 Apr. 1983. his predecessors. At the time of his election he was vice-president and head of the General Motors department. He was elected president in a very close threeway race by a slim majority of the executive board. He will have to lead the UAW in a very uncertain period, when membership is falling and employment in the automobile industry is not growing. In addition, he will have the challenging task of negotiating the successor contract to the concession agreements.

The UAW case contrasts somewhat with the UMW, since the former has not had as abrupt a switch in types of leader. All of the leaders of the UAW have come up through the union bureaucracy. Bieber was 52 years old when elected president, not of the same generation as the UMW's 33-year-old Trumka. The membership of the UAW seems content to stay with leaders drawn directly from the union hierarchy.

\section{The AFL-CIO}

The final case is the most dramatic example of a change in leadership, that of the change in the AFL-CIO's presidency from George Meany to Lane Kirkland. As already indicated, Kirkland is the typical union bureaucrat. He is a college graduate, with experience running a large organization. He had been secretary-treasurer of the AFL-CIO for ten years and was hand-picked by Meany to be his successor. ${ }^{21}$ Meany, on the other hand, was one of the real founders of the American labor movement, a leader in the Gompers tradition. ${ }^{22} \mathrm{He}$

21. Gifford, Directory of U.S. Labor Organizations, 1982-83, p. 6.

22. Gus Tyler, "Leadership Training for the Future," in Trade Unionism in the United States: A Symposium in Honor of Jack Barbash, ed. James L. Stern and Barbara D. Dennis (Madison: University of Wisconsin, 1981), p. 123. 
was not a technocrat by any means; he was more of the old school: the rough and ready leader who fought to put the labor movement in a position of power and keep it there against old and new enemies. His style and philosophy did not please everyone in the labor movement and led to a break on strict ideological grounds with Walter Reuther and the UAW in 1968. The transition of AFL-CIO leadership has been truly that of the old guard to the union bureaucrat.

\section{THE ROLE OF WOMEN AND MINORITIES}

Women and minorities are better represented in union leadership positions than in the past, but still in lesser numbers than their proportion in the labor movement or in the work force. Women form an integral part of the labor market, comprising 43 percent of the labor force. Almost 63 percent of all women between the ages of 18 and 64 are in the labor force. ${ }^{23}$ The proportion of women members in unions has been increasing, from 16.6 percent in 1954 to 24.2 percent in 1978 . When we include both unions and associations, the proportion of women members rises to 28.1 percent in 1978 and 30.1 percent in 1980.24

In 1978 there were only three AFL$\mathrm{CIO}$ unions with as many as two female officers. Of the 1026 officers of AFL$\mathrm{CIO}$ and unaffiliated unions, 67 , or 6.6 percent, were female. The percentage for employee associations was slightly

23. U.S., Bureau of Labor Statistics, Employment and Earnings, 30(1):142 (Jan. 1983).

24. Directory of National Unions and Employee Associations, 1979, p. 62; and Directory of U.S. Labor Organizations, 1982-83, p. 3. Women members accounted for 60 percent of total employee association membership. over 25 percent, thus giving a total for the entire labor movement of 10.7 percent who are female officers. ${ }^{25}$ As of 1981 there were no women presidents of AFL-CIO-affiliated unions. ${ }^{26}$ There were some women presidents of independent unions, most of which were quite small. ${ }^{27}$

There is slightly better representation of women on executive boards of unions: 7.2 percent of all union board members are women. Associations were once again higher, with 35.3 percent of their board members being women. There are some unions with high representation of women on their executive boards-such as the Flight Attendants, whose board has 56 women out of 61 members; the Amalgamated Clothing and Textile Workers Union (ACTWU), with 6 out of 47; the American Federation of Teachers with 8 out of 31 ; and the National Education Association, whose board is almost 50 percent female. Nearly all of the 50 state AFL-CIO executive boards have at least one female member. ${ }^{28}$ However, there were only 9 out of 173 officers of state AFL-CIOs who were women.

On the 35-member AFL-CIO executive board, there are currently two women: Joyce Miller of the ACTWU

25. Officers include president, vice-presidents, and secretary-treasurer. The source is Directory of National Unions and Employee Associations, 1979.

26. The Association of Flight Attendants, which is a division of the Air Line Pilots Association, had a woman as president in 1981 .

27. The exceptions were some school employee associations. The largest unions headed by women were the Ohio Association of Classified School Employees, with 28,373 members, and the Ohio Civil Service Employees Association, with 17,260 members. The source is the Directory of National Unions and Employee Associations, 1979.

28. Directory of National Unions and Employee Associations, 1979, p. 95. 
and president of the Coalition of Labor Union Women (CLUW), and Barbara Hutchinson of the American Federation of Government Employees (AFGE). These women were appointed to the executive board in 1980 and 1981, respectively. Prior to 1980 the board was all male.

Although these figures suggest that the proportion of women in leadership is far from approaching that of women in membership, this discrepancy may not be that much greater than exists between the rank and file and the political elite of other groups in society. For instance, the discrepancy between the proportion female in the population51 percent-and the proportion of women in the U.S. Congress--less than 5 percent-is striking also.

Even though the percentage of female union membership is growing, Rattner and Cook argue that this increase is not due to a concerted effort on the part of labor to organize women, but to the fact that newly organized industries are disproportionately female. ${ }^{29}$ Even if this is

29. Ronnie Steinberg Rattner and Alice Cook, Women, Unions and Equal Employment Opportunity, Working Paper 3, (Albany, NY: Center for Women in Government, 1981), p. 1. For a discussion of women and trade unions see, Barbara Wertheimer, We Were There (New York: Pantheon Press, 1977); Barbara Wertheimer and Anne Nelson, Trade Union Women (New York: Praeger, 1975); Michele Hoyman, "Labor Unions and Civil Rights Compliance" (Ph.D. diss. University of Michigan, 1978); Alice Cook, "Women and American Unions," The Annals of the American Academy of Political and Social Science, 124 (Jan. 1968); Virginia Bergquist, "Women's Participation in Labor Organizations," Monthly Labor Review, 10:97, 3 (Oct. 1974); Michele Hoyman, "Leadership Responsiveness in Local Unions and Title VIl Compliance: Does Democracy Mean More Representation for Blacks and Women?" in Proceedings of the Thirty-second Annual Meeting of the Industrial Relations Research Association the case, there have been a number of active women's groups formed recently, such as Women Employed, which have launched successful organizing drives, coupled with litigation on behalf of female workers in the clerical and banking industries. ${ }^{30}$ Women still tend to be concentrated in nonmanufacturing in general, where they make up 46.4 percent of all workers, and services in particular, where they are almost 60 percent of the work force. This is the area in which overall union growth has occurred. In manufacturing only 32.3 percent of employees are women. ${ }^{31}$ Given this, it is expected that the proportion of female union members will continue to grow.

Further, there have been some recent events suggesting that the status of women in leadership positions in unions may be changing. First, there is the formation of CLUW, founded in 1974, which currently has 18,000 members. It has among its goals to organize unorganized women, to increase participation of women within their unions, and to lobby for political action and legislation beneficial to women.

There is evidence to suggest that CLUW is making great changes as a

(Madison, WI: IRRA, 1980); Karen Koziara and David Pierson, "Barriers to Women Becoming Union Leaders," in "Proceedings of the Thirtythird Annual Meeting of the Industrial Relations Research Association (Madison, WI: IRRA, 1981), pp. 48-54; and Alice Cook, The Trade Union Movement and Working Women (Paper presented for the World Congress of Sociology, Uppsala, Sweden, Aug. 1978).

30. See Elyse Glassberg, Naomi Baden, and Karin Gerstel, Absent from the Agenda: A Report on the Role of Women in American Unions (New York: Coalition of Labor Union Women, Center for Education and Research, 1980).

31. U.S., Bureau of Labor Statistics, Employment and Earnings, 1:30, 165 (Jan. 1983). 
result of its advocacy role. Lane Kirkland recently appointed Joyce Miller, in her capacity as head of CLUW, to the AFL-CIO executive board. In addition, there have been a number of drives launched by CLUW in order to educate and lobby on women's issues. ${ }^{32}$ Women are making gains in the union movement, but they are mainly at the second level of power. ${ }^{33}$ The following quotation from Joyce Miller describes the prospects for increases in women's leadership:

The 80 s is the decade of women advancing to leadership on the local levels. We see more and more women elected as local presidents, central labor council presidents, state federation secretary-treasurer, etc. As women swell the ranks of union membership on the rank and file level and begin to move even further on the local level, we will see the possibility of a woman union president, women state federation presidents, etc. By 1990 we should be better situated in terms of national leadership. $^{34}$

The literature on blacks and minorities in unions by such authors as Hill and Gould indicates that there may have been substantial underrepresentation of blacks and minorities in unions, on both local and international levels, due to barriers to their participation. ${ }^{35}$ In addi-

32. For a description of these issues see Glassberg, Baden, and Gerstel, Absent from the Agenda.

33. Some examples are the American Federation of Teachers, the Communication Workers of America, the International Ladies Garment Workers Union, and the Service Employees. The source is the Directory of National Unions and Employee Associations, 1979.

34. Miller to Michele M. Hoyman, June 1983.

35. The principle of exclusivity means that there is an exclusive bargaining agent for all employees. There are no provisions made to represent minorities. See Herbert Hill, Black Labor and the American Legal System: Race, Work and the Law (Washington, DC: Bureau of National Affairs, 1977) and William B. Gould, tion, voting for union office is at-large, and minorities cannot be sure of electing someone to any leadership position because in most cases they are also a minority in the union. In some unions it took strong downward pressure from the leaders on the members to elect the first black officer. ${ }^{36}$

Although this article concentrates on blacks because they are the largest single minority, there are other important minorities critical to the future of the American labor movement and particularly to the leadership of the labor movement, such as Chicanos. The United Farm Workers is a union that has been described in its organizing efforts as almost synonymous with the expression of an ethnic movement. This is the case because of the overwhelming proportion of migrant workers who are Chicano and because the leadership is Chicano. ${ }^{37}$

Black Workers in White Unions: Job Discrimination in the U.S. (Ithaca, NY: Cornell University Press, 1977). For more on the subject see Ray Marshall, Employment of Blacks in the South: A Perspective on the 1960s (Austin: University of Texas Press, 1978); Ray Marshall, Employment Discrimination: The Impact of Legal Administrative Remedies (New York: Praeger, 1978); and Herbert Hill, "The AFL-CIO and The Black Worker: Twenty-five Years After the Merger," Journal of Intergroup Relations, 10(1):5 (Spring, 1982).

36. Ralph Orr, "Equality at the Union Halls Didn't Come Without a Fight," Detroit Free Press, 2 Dec. 1980.

37. See Karen Koziara, "Agriculture," in Collective Bargaining: Contemporary American Experience, ed. Gerald G. Somers (Madison, WI: Industrial Relations Research Association, 1980), pp. 263-314; Karen Koziara, "Agricultural Labor Relations in Four States--A Comparison," Monthly Labor Review, I00(5):14 (May 1977); and Michael Dempsey, "Si Se Puede: An Examination of Agricultural Collective Bargaining in California. An Assessment of the California Agricultural 
In 1980 the category "black and others" accounted for 12.4 percent of the total civilian labor force. Of this classification, 81.3 percent were black. ${ }^{38}$ Of all organized workers, 14.9 percent were in the black-and-others category. The percentage of black workers who were union members-29 percent-was higher than that for whites -22.2 percent. ${ }^{39}$

The information on blacks in leadership roles is not as complete as that for women. There are two blacks currently serving on the executive board of the AFL-CIO: Frederick O'Neal-president of the Associated Actors and Artists of America, which is the only union with a black president -and Barbara Hutchinson-director of Women's Activities for the AFGE. There are other high ranking black officers, such as William Lucy, secretary-treasurer of American Federation of State, County, and Municipal Employees (AFSCME), and Roosevelt Watt, secretary-treasurer of the Transport Workers Union. There are also many black vice-presidents throughout organized labor, such as Marc Stepp of the UAW and Leon Lynch of the United Steel Workers. As of 1979, 7 of the 34 vice-presidents of the American Federation of Teachers were black. ${ }^{40}$

Although the number of black union presidents is very low and the representation of blacks at the second tier of leadership is not high either, the numbers are growing. The creation of the Coalition of Black Trade Unionists

Labor Relations Act, Implications for National Legislation"(M.A. tutorial, University of Illinois, 1980).

38. U.S., Bureau of Labor Statistics, Employment and Earnings, 1:28, 164 (Jan. 1981).

39. Gifford, Directory of U.S. Labor Organizations, $1982-83$, p. 51 .

40. This is taken from information provided by the AFL-CIO Department of Civil Rights.
(CBTU) in 1972 has served as a focal point for blacks who want to move up in the labor movement. Like CLUW, it is not a separatist movement, but one that is pledged to work within the framework of the trade union movement. ${ }^{41}$ It is probable that gains in the union movement by blacks at the staff level will continue and the number of second-tier leadership positions will continue to grow. A key question is whether a black will be elected president of a large industrial union in the near future. Recent presidential openings in two unions, the UAW and AFSCME, had potential black candidates-Stepp and Lucy, respectively-but neither was chosen. It may be some time before there is a black or a woman as president of a large industrial union in the United States.

\section{THE LABOR LEADER OF THE 1990s}

The image of the labor leader is clearly changing, but in many ways it is just a reflection of the changing image of the labor movement. Before the passage of the Wagner Act, the labor leader had a precarious position, because there was no legal protection for the process of unionization and for the union itself if it was not recognized by the employer. The major organizing occurred in the 1930 s and was often quite turbulent. This required a leader who could both command the attention of the workers and stand up to the tactics of management. Thus the legendary union leaders were born.

As the labor union became a more accepted part of the American econ-

41. Gil Green, What's Happening to Labor? (New York: International Publishers, 1976), p. 229. 
omy, the attributes of a labor leader began to change out of necessity. It was still necessary to command the attention of the workers, but not in the same way as was needed to convince them to join the union in the first place. Modern labor leaders must be able to understand and utilize the new and sometimes complex labor laws that have arisen since the 1930 s. With the growth of major unions into bureaucracies, it is now important that the leader be able to run a large organization. Thus the profile for a union leader today is quite different from the one that was necessary to form the union originally. The position requires an administrator rather than an organizer. Thus we are seeing the union bureaucrat rise to the top more frequently.

In the 1980s there has been much debate about the changing role of unions and collective bargaining in the United States. One can argue about whether collective bargaining is at a crossroads or whether concession bargaining is here to stay. One thing that is clear is that some major unions are in industries that have been suddenly faced with increased competition, either from abroad or domestically, over which the union has no control. This poses a new threat to unions, one that requires a new type of strategy. As we move into the 1980 s the labor leader is more likely to be a professional who can deal with the new set of circumstances.

However, professionalism is not enough to get someone elected to the union presidency. There is still a constituency to be served and a power base to be built. Since most union presidents are elected at conventions, it is necessary to build a power base within the existing leadership in order to move up.
The probability of a union leader being a woman or a member of a minority is still small. For a variety of reasons previously discussed, no major American union is currently headed by a black or a woman. They are making some progress on the second level of powerthe union vice-presidencies and executive boards-but the union presidents club is still a white male bastion for the most part.

What will the labor leader of the 1990s look like? He will most probably still be a white male. He will have more education than his earlier predecessors and he will be an administrator. The union bureaucrat will probably still dominate the union presidencies. This is due to the fact that unions have also been reluctant to turn to anyone other than an insider who knows the ropes. ${ }^{42}$ The qualifications will require more of an understanding of the legal aspects of trade unionism as well as an understanding of how unions fit into the American economy of the 1990s. The one area in which an outside professional might move into a union presidency would be in the case of a union with declining membership that has direct election of officers. In this case, the rank and file could turn to the professional-for example, Trumka-to save them from their situation.

We are witnessing a new generation of labor leaders as a result of the changing role of unions in society. The modern union leader has to be more skilled

42. Derek C. Bok and John T. Dunlop, Labor and the American Community (New York: Simon and Schuster, 1970), p. 174; and Lois Gray, “Unions Implementing Managerial Techniques," Monthly Labor Review, 104(6):3 (June 1981). 
in dealing with the media than in the past. It may be that the union member knows more about the union leader from the evening news than from direct contact. The labor leader of the 1990s has to be a great deal more flexible than the labor leader of the 1930s, because threats to the union now come in more subtle forms. In the 1930s the employer was the enemy that had to be overcome in order to organize; in the 1990 s the enemy could be foreign competition, or the nonunion sector, or a hostile government, or a slick consulting firm guaranteeing a union-free environment. The health of the union movement in the 1990s will in many ways depend on how well the union leaders of the 1990s are prepared for their jobs and how well they perform in office. 